\title{
Alluvial-eolian interaction in a Cambrian rift margin: the Pedra das Torrinhas and Pedra Pintada formations (Guaritas Group, RS)
}

\author{
ANDRÉ MARCONATO ${ }^{1}$, RENATO P. ALMEIDA ${ }^{2}$, MAURÍCIO G. M. SANTOS ${ }^{1}$, \\ JORGE E.S. NÓBREGA ${ }^{1}$ and ROGÉRIO B. SOUZA ${ }^{3}$ \\ ${ }^{1}$ Programa de Pós-Graduação em Geoquímica e Geotectônica, Instituto de Geociências, Universidade de São Paulo \\ Rua do Lago, 562, Cidade Universitária, 05508-080 São Paulo, SP, Brasil \\ ${ }^{2}$ Departamento de Geologia Sedimentar e Ambiental, Instituto de Geociências, Universidade de São Paulo \\ Rua do Lago, 562, Cidade Universitária, 05508-080 São Paulo, SP, Brasil \\ ${ }^{3}$ Petróleo Brasileiro S.A., Universidade Petrobras \\ Rua Ulisses Guimarães, 565, Cidade Nova, 20211-225 Rio de Janeiro, RJ, Brasil \\ Manuscript received on November 26, 2008; accepted for publication on April 6, 2009; \\ presented by ALCIDES SIAL
}

\begin{abstract}
This work presents a study of selected outcrops from the Pedra das Torrinhas Formation of the Guaritas Group (Cambrian, Camaquã Basin), near the basin bordering Encantadas Fault Zone. The studied succession includes alluvial fan deposits that pass laterally into eolian deposits. Sedimentary facies and architectural element analysis were performed, followed by sedimentary petrography and microscopic porosity analysis, aiming to characterize the porosity of the deposits and its spatial distribution. The main objective was to contribute to a better understanding of the porosity spatial distribution in depositional systems characterized by the interaction between alluvial and eolian processes, with special reference to deposits formed prior to the development of terrestrial plants. Porosity values are related to depositional processes, with higher porosities associated to eolian dune deposits (mean of 8.4\%), and lower porosity related to interdunes (mean of $3.4 \%$ ) and alluvial fans (mean of $4.3 \%$ ). Architectural elements analysis revealed the spatial relationships of these deposits, a response to the interplay of the eolian and alluvial processes. The integration of porosity data reveals that the interaction of alluvial and eolian processes results in heterogeneous distribution of porosity at the facies association scale. Eolian reworking of alluvial facies increases porosity whereas sheet-flood and other alluvial processes in the interdune areas reduce porosity.
\end{abstract}

Key words: alluvial-eolian interaction, Pedra das Torrinhas Formation, Cambrian, reservoir analogue models, marginal rift facies.

\section{INTRODUCTION}

Prior to the evolution of land plants in the Early Paleozoic, subaerial depositional systems were very sensible to variations in rainfall, which caused great variations in surface run-off when well developed soils were absent (Went 2005). In that sense, those systems were similar

Correspondence to: André Marconato

E-mail: andre.marconato@usp.br to modern arid depositional environments, which commonly show interactions between alluvial and eolian systems (Bullard and Livingstone 2002), frequently in the form of reworking of fluvial and alluvial fan deposits by eolian processes (El-Baz et al. 2000, Maroulis et al. 2007, Veiga and Spalletti 2007).

On the other hand, the influence of river systems in eolian dune fields has been documented even in the most arid of the modern environments (e.g. Langford 
1989, Tooth 2000, Stanistreet and Stollhofen 2002, Stromback et al. 2005). The interaction between eolian systems and alluvial fans is less documented (Clemmensen and Abrahamsen 1983, Gardner et al. 2006), and even less documented are the interactions of such systems before the evolution of land plants (Hadlari et al. 2006, Paim and Scherer 2007). This work presents facies analysis of well-exposed successions recording the interactions of alluvial fans and an eolian dune field in the Cambrian successions of the Pedra das Torrinhas and Pedra Pintada formations, Camaquã Basin, Rio Grande do Sul State (Southernmost Brazil).

Alluvial and eolian depositional systems are responsible for hydrocarbon reservoirs and large scale aquifers, being the preferential targets for depositional architecture studies in recent years.

Detailed facies models have been developed for the main alluvial depositional systems (e.g. Collinson 1996, Miall 1996), as well as eolian systems (e.g. Brookfield 1992, Kocurek 1996) with an increasing interest in the particularities of the interactions among both systems (e.g. Langford 1989, Langford and Chan 1989, Stanistreet and Stollhofen 2002, Paim and Scherer 2007), with descriptions of the resulting depositional architecture (e.g. Herries 1993, Fischer et al. 2007). The quality of the here presented expositions enables a 3D architectural analysis, making it possible to document the spatial variation of the porosity of sedimentary rocks at several scales. Thus, the interaction between the Pedra das Torrinhas and Pedra Pintada formations, reported here in terms of facies and porosity analysis, may be used as an analog for the less exposed deposits in which the porosity heterogeneities are controlled by the interaction of alluvial fans and eolian processes, with applications to hydrocarbon and water reservoir studies, especially in rift basins.

\section{GEOLOGICAL SETTING}

The Camaquã Supergroup comprises more than $10 \mathrm{~km}$ thick of sedimentary and volcanic successions of Ediacaran to Early Cambrian age that crop out near Brazil's southern border, in the Rio Grande do Sul State (Fig. 1). The Supergroup is divided into five main units, from base to top: the Maricá Group (siliciclastic successions), the Bom Jardim Group (volcanic and volcano-sediment- ary successions), the Acampamento Velho Formation (volcanic succession), the Santa Bárbara Group (siliciclastic successions), and the Guaritas Group (siliciclastic successions).

The Guaritas Group, the uppermost unit of the Camaquã Supergroup, was deposited in a NNE-SSW trending basin that is $50 \mathrm{~km}$ wide and more than $150 \mathrm{~km}$ long. The basin is bounded by high-angle faults that uplifted Paleo and Neoproterozoic metamorphic rocks of the Dom Feliciano Belt and the Rio Vacacaí island arc terrane (Fragoso-Cesar 1991), being interpreted as a continental rift on the basis of its tectono-stratigraphic evolution (Almeida et al. 2009). The Guaritas Group was deposited during the Early Cambrian, as indicated by the soft-sediment deformation features that occur at the contact with shallow sills of the 535 Ma Rodeio Velho Intrusive Suite (Almeida 2005).

The Guaritas Group is a succession with more than $1,500 \mathrm{~m}$ thick that is formed by pebbly sandstones, conglomerates, sandstone-mudstone rhythmites and fineto medium-grained sandstones with eolian stratification. The group is divided into five main units (Fig. 2), from base to top: Guarda Velha Formation (Ribeiro and Lichtenberg 1978), Varzinha Formation (Ribeiro and Lichtenberg 1978), Pedra Pintada Formation (FragosoCesar 1991), Pedra das Torrinhas Formation (FragosoCesar 1991), and Serra do Apertado Formation (Almeida 2005). The sandstones are mineralogically immature, ranging from arkoses to lithic arkoses. Since Robertson (1966) and Ribeiro (1970), the Guaritas Group is understood to be formed by continental depositional environments, including eolian dune field deposits (e.g. Becker and Fernandes 1982, A.R.S. Fragoso-Cesar, unpublished data, Lavina et al. 1985, Paim 1994, Paim et al. 2002, Paim and Scherer 2003, 2007), alluvial fan deposits (e.g. Ribeiro and Lichtenberg 1978, Almeida 2005, Almeida et al. 2009) and ephemeral river deposits (e.g. Paim 1994, 1995, Paim et al. 2002, Almeida 2005, Almeida et al. 2009), some facies of which have been alternatively interpreted as lacustrine deposits (Paim 1994).

\section{METHODS}

In order to characterize the three-dimensional variation of sedimentary attributes and the depositional environments, sedimentary facies and architectural ele- 


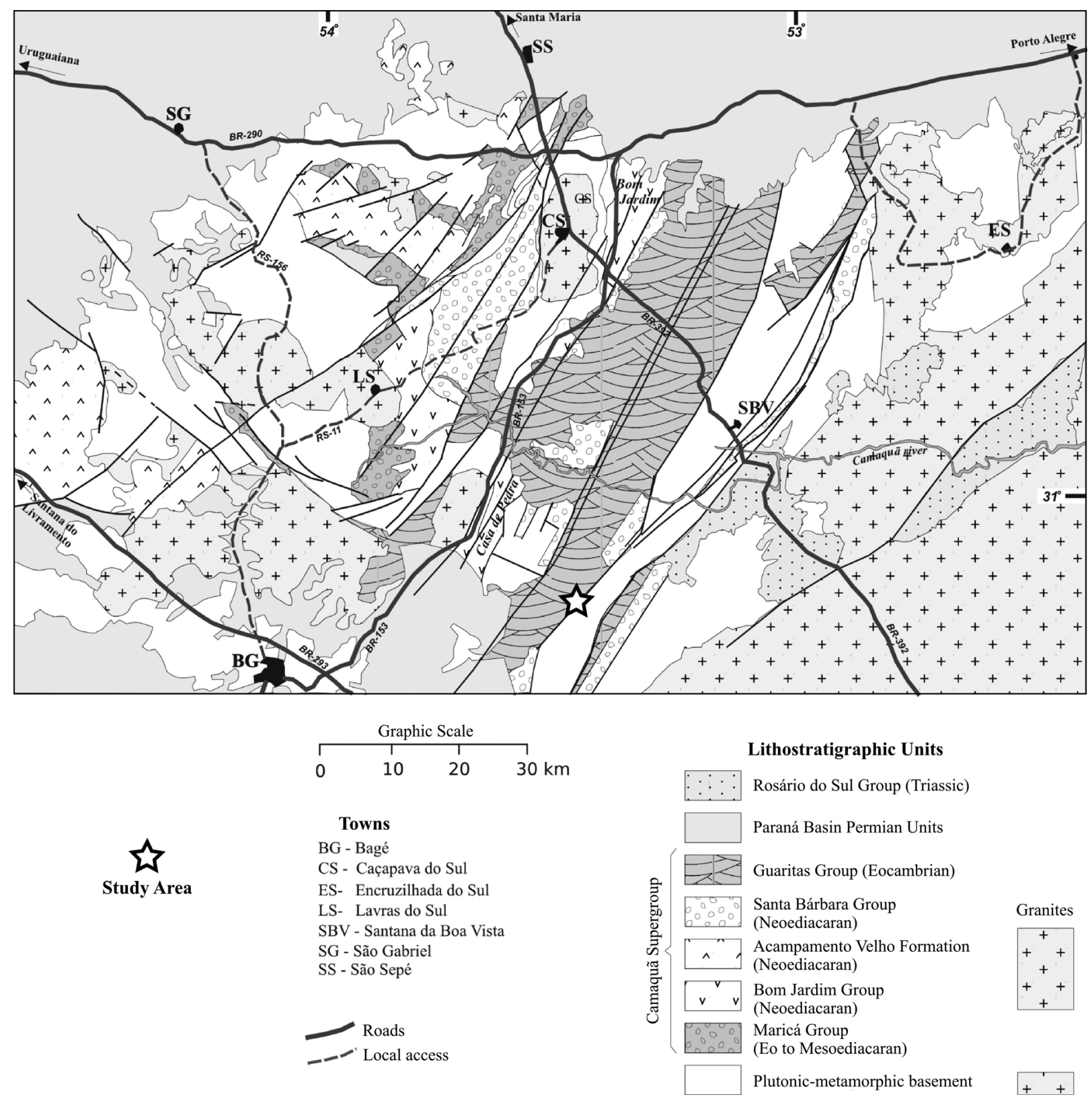

Fig. 1 - Camaquã Basin and surrounding areas with the location of the study area.

ment analysis were applied to selected outcrops of the Pedra das Torrinhas and Pedra Pintada formations. Facies analysis followed the method described by Reading (1986), Walker (1992) and Miall (2000), and the architectural elements analysis was based on Miall (1985, 1996).

Pebble and cobble data were obtained in order to characterize alluvial fan and braided river source areas.
In each counting site at least 100 clasts were analysed and ascribed to acid volcanics (V), granites (G), mylonites and low-grade metamorphic rocks (M), in order to be plotted in a ternary diagram.

Petrographic analysis was conducted in representative samples from the described sedimentary facies, which were classified according to each facies association in order to interpret the relationships between de- 

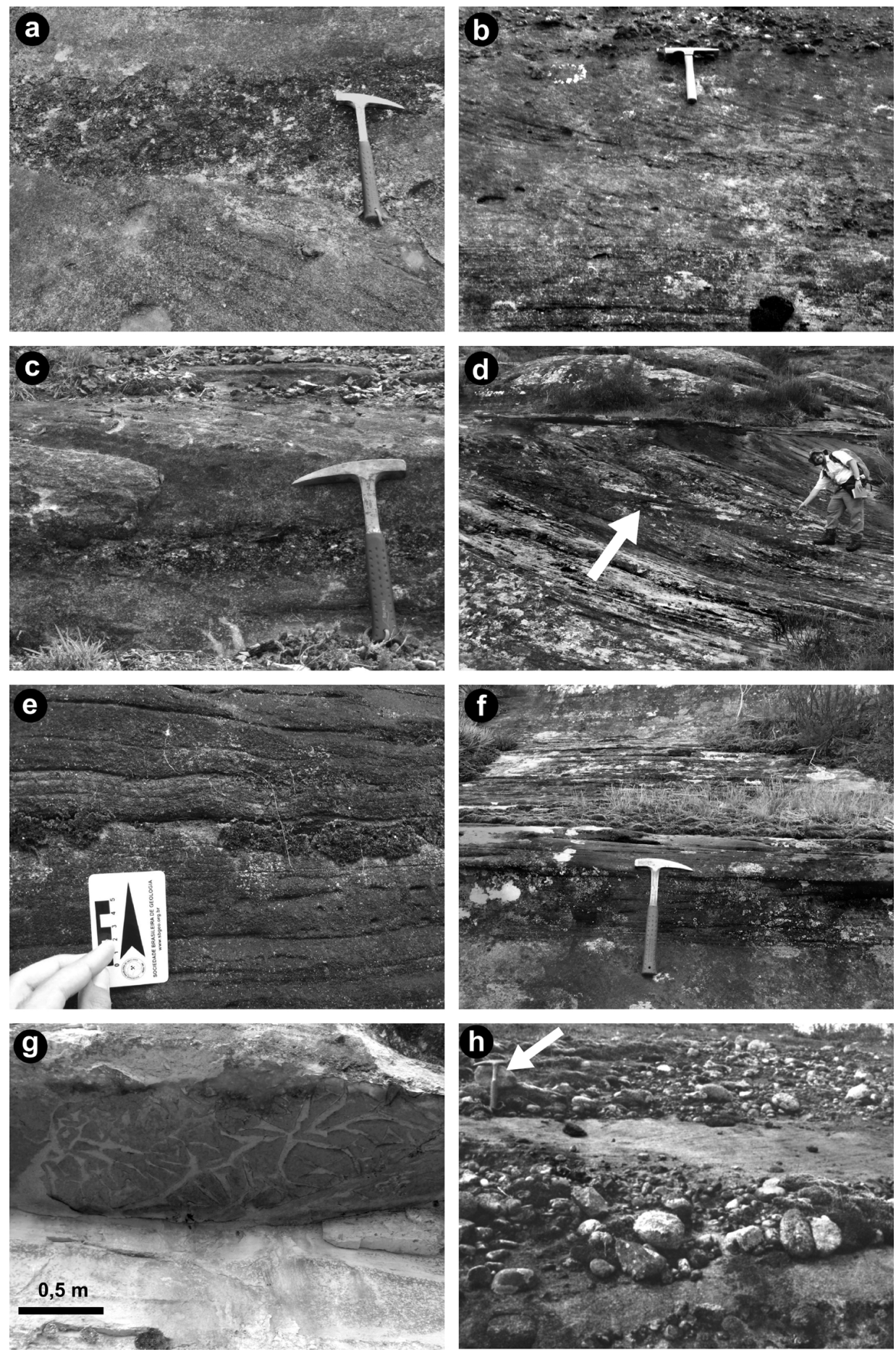

Fig. 2 - a) Conglomeratic facies F1 in cut-and-fill structure associated to F3 facies with sandstones; b) Alluvial fan facies association: F2 facies (base) followed by two sets of F5 facies and, on the top, interbedded F1 lenses; c) F4 facies above a thin conglomeratic lens; d) F6 facies, showing a 2nd order surface (arrow), followed by F8 facies on the top of the succession. e) F7 facies showing climbing ripples (climb angles near to 90o); f) F8 facies with metric scale plane-bedded series; g) Outcrop of F9 facies showing dessication cracks; h) Braided river facies association presenting lenses ( $20 \mathrm{~cm}$ thick) of sandstones of F5 facies, interlayered with deposits of F10 facies. Hammer as scale on the upper left corner. 
positional processes and the resulting petrographic characteristics.

Paleocurrents were measured in cross-stratified sandstones in order to determine sedimentary transport trends while source-areas were inferred from pebble lithology from conglomerates.

The porosity analysis of sandstone was performed in thin sections impregnated with blue stained epoxi resin in order to evaluate the porous area with a digital image analyzer connected to a petrographic microscope. As a comparative criteria, inter-granular pores filled with cement were visually estimated in order to verify if there were any facies controls on the original porosity, which would have been masked by cementation and the development of intra-granular porosity.

\section{FACIES ASSOCIATIONS}

Three facies associations were described in the studied area, each one corresponding to a different lithostratigraphic unit. The two lower facies associations correspond to the Pedra das Torrinhas and Pedra Pintada formations, and were interpreted respectively as alluvial fan and eolian dune field deposits. A few kilometers from the basin border fault, the alluvial fan facies association displays a lateral transition into the eolian facies association. The upper facies associations was interpreted as braided river deposits and corresponds to the Serra do Apertado Formation, which is separated from the lower units by a regional disconformity (Paim et al. 2002, Paim and Scherer 2003, 2007, Almeida 2005).

Under microscopic analysis, sorting is the main feature that differentiates the sandstones from each facies associations. Compaction and cementation, on the other hand, are very similar in samples from all facies associations. Cementation is mainly represented by carbonatic cement filling primary and secondary pores, followed by intergranular kaolinitic cement. Quartz overgrowth is rare and ferruginous cement occurs as thin grain coatings. Primary pores are usually enlarged by secondary dissolution, resulting in elongated pores; floating grains and secondary pores are the product of feldspar or lithic fragments dissolution and grain fracturing. Porosity reduction by cementation is common and more intense in fine-grained samples.

\section{Alluvial Fan Facies Association}

The alluvial fan deposits are restricted to the surroundings of the basin border fault and composed mostly of conglomerates and breccias, which are poorly sorted, immature and often contain imbricated angular pebbles to cobbles. These lithotypes are associated with fineto medium-grained arkoses, commonly including sparse clasts. The alluvial fan facies association comprises the following sedimentary facies:

\section{- Breccias and conglomerates with imbricate clasts}

(F1) are massive to crudely stratified and composed mostly of granite and mylonite clasts. Conglomerate layers are 15 to $30 \mathrm{~cm}$ thick and commonly occur in cutand-fill structures (Fig. 2a) or as metric tabular sheets (Fig. 2b). Clasts are up to $25 \mathrm{~cm}$ long, composed of mylonitic granites, quartz mylonites, granites, rhyolites and rare chlorite schists. Breccias beds occur where mylonite provenance prevail. Imbrication is predominantly parallel to the intermediate axis of the tabular clasts.

- Conglomerates and breccias with plane bedding

(F2) consist of sheets to broad lobes of clast-supported conglomerates with sub-angular clasts and breccias that are laterally continuous for over $300 \mathrm{~m}$, with 20 to $60 \mathrm{~cm}$ thick. Up to $30 \mathrm{~cm}$, mylonite clasts eroded from the adjacent basement are the most common constituents of the conglomerate framework. Internally, each bed of this facies is composed of a coarser, lower, decimeter-scale layer of stratified conglomerate or breccia and an upper, decimeter to centimeter-scale layer of plane-bedded pebbly sandstone (Fig. 2b). This facies occurs as tens of meters thick amalgamated beds.

- Laminated sandstones (F3) are medium to coarse grained with sparse granules and display planar lamination. They are frequently associated with F1, and occur as 10 to $20 \mathrm{~cm}$ thick sheets or broad lenses, sometimes overlain by cut-and-fill structures of $\mathrm{F} 1$.

- Tabular cross-stratified sandstones (F4) are medium to coarse grained, with sparse granules, and show low angle cross stratification (Fig. 2c). This facies occurs as 10 to $20 \mathrm{~cm}$ thick tabular layers of metric extension or less frequently as metric lenses. These lenses and tabular layers are commonly overlain by F1 cut-and-fill structures. 
- Trough cross-stratified sandstones (F5) are mediumto coarse-grained, with sparse granules. They occur as 10 to $20 \mathrm{~cm}$ thick lenses interbedded with $\mathrm{F} 1$ facies (Fig. 2b).

\section{Provenance analysis}

The alluvial fan facies association was analyzed in four sites, distributed in a section nearly perpendicular to the basin border. The more abundant clasts, which usually comprises more than $20 \%$ of each sample, are composed of mylonitic granite and quartz-mylonites; thus, in the ternary diagrams, they plot near the metamorphic vertices. Although Chlorite schist is also present (rarely reaching 20\%), they are absent in sites away from the border fault, whereas rhyolite clasts become more frequent basinwards, leading to an acid volcanics enrichment trend in the ternary diagram (Fig. 3).

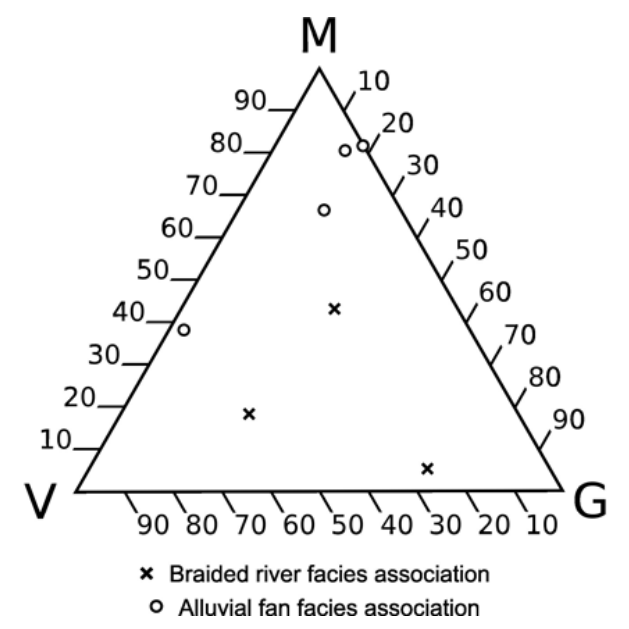

Fig. 3 - Ternary diagram (pebble composition) of the alluvial fan and braided river deposits. $\mathrm{M}$ - Various mylonites and low-grade metamorphic rocks; G-Granites; V-Acid Volcanic rocks.

\section{Petrography}

Alluvial fan deposits present a subtle grain size reduction from the base to the top of the succession, where there is also evidence of eolian reworking. Sandstones range from medium- to coarse-grained, with scattered granules, and present poor to very poor sorting and angular to sub-angular grains. Alluvial sandstones that may have an origin in reworked eolian deposits, as described by Paim (1994, 1995) and Paim et al. (2002), are mediumgrained, have sub-rounded grains, and are better sorted.

\section{Interpretation}

The described facies and their spatial relationships suggest that this facies association is the product of sheetflood dominated alluvial fans (Blair and McPherson 1994). Clast imbrication in F1 indicates that pebbles and bigger clasts rolled on the bed surface and, thus, were transported as bed-load in traction currents (Walker 1975). The sheet-like form of most beds of F1, the presence of cut-and-fill structures and the association with beds of F3 suggests unconfined flow events, with peak discharge before deposition and capable of eroding the previous deposits. Moreover, F2 facies also suggests unconfined flow and is similar to the deposits described by Blair (1999), who interpreted them as the product of sheet-floods in alluvial fans. Cross-stratified facies (F4 and F5) reflect reworking of sheet-flood lobes by channelized lower-flow regime currents during waning flow, in a similar way as described by Blair (1987). F4 and F5 are respectively interpreted as the product of sub-aqueous straight-crested and sinuous-crested dunes, generated by unidirectional traction currents (Harms 1979).

\section{Eolian Dune Field Facies Association}

The succession dominated by moderately sorted sandstones of the Pedra Pintada Formation presents diagnostic features that allow the identification of an eolian origin.

- Trough cross-stratified sandstone with pin-stripe lamination (F6) is fine to medium grained and show medium- to large-scale trough cross-stratification. Individual sets range from $0.4 \mathrm{~m}$ to $5 \mathrm{~m}$ thick. The thickest sets are found far from the Encantadas Fault Zone, while towards the basin border the sets become smaller, rarely reaching one meter. Pin-stripe lamination (Hunter 1977, Fryberger and Schenk 1988) is conspicuous (Fig. 2d).

- Sandstones with climbing ripples (F7) are fine to medium grained and show supercritical climbing of symmetric to asymmetric ripples (Fig. 2e). Within successions dominated by F6, this facies commonly passes laterally into F8.

- Laminated sandstones (F8) are fine to medium grained and present plane bedding to low angle lamination, organized in centimeter to meter thick strata (Fig. 2f). These deposits may contain mudstone intraclasts and deflation lags. 
- Cracked mudstones (F9) occur in millimeters to a few centimeters thick drapes (Fig. 2g), overlying F7 and F8.

- Conglomerates with imbricate clasts (F1) also occur in the eolian dune field facies association, as 10 to $20 \mathrm{~cm}$ thick, fining-upward layers with erosive bases.

\section{Petrography}

Samples of the eolian dune facies are generally medium-grained, with moderate grain sorting and subrounded grains. Packing is closed, with evidence of mechanical compaction, such as plane and concave-convex contacts among grains. Sandstones from interdune deposits are fine- to medium-grained, with moderate sorting and sub-rounded grains. Packing is usually closed. Thin sections of samples from the contact between sandstone and siltstone show a progressive loss of porosity associated to the decrease of the grain size from finegrained sand to silt.

\section{Interpretation}

F6 is interpreted as the product of migrating eolian dunes. Its stratification is marked by pin-stripe lamination that results of the differential weathering of grainfall and grainflow strata, as described by Hunter (1977) and Fryberger and Schenk (1988). The trough crossstratification suggests barchan or barchanoid dunes (McKee 1966). Thickness of individual sets decrease towards the basin border; it is probably due to a lower preservation, as described by Clemmensen and Abrahamsen (1983) in a similar context. The relationship between F1, F7, F8 and F9 facies and eolian facies (F6) suggests a flooded interdune context for these deposits. F1 is interpreted as unconfined flow deposits in interdune areas, recording the flood events. F7 records waning flood deposition of sand simultaneously from suspension and traction. F8 indicates previous eolian deposits reworked by tractive currents during fluvial floods in interdune areas. F9 is interpreted as settling deposits from standing water bodies in flooded interdunes, with subsequent subaerial exposition and desiccation.

\section{Braided River Facies Association}

Braided river deposits overlie both the previous facies associations and present three sedimentary facies, two of which are also found in the previously described facies associations.

- Lenticular stratified conglomerates (F10) consist of lenses of clast-supported conglomerates with rounded pebbles to boulders, which are imbricated parallel to their intermediate axis. Sets are 20 and $50 \mathrm{~cm}$ thick, preserved in cut-and-fill structures or as several meters wide and long lenses (Fig. 2h). Lower boundaries are often erosional, and the upper ones may be either sharp or gradational to F4 and F5. Most of these bodies are crudely stratified, with plane bedding defined by alternation of coarser- and finer-grained strata. Locally, lowangle cross-stratified foresets can be seen, sometimes with coarse-grained sandstone layers that stress the stratification. Clasts are most composed of several types of granites, quartz and rhyolites.

- Tabular cross-stratified sandstones (F4) also present in the braided river facies association, occur as isolated lenses of 20 to $50 \mathrm{~cm}$ thick, within successions dominated by $\mathrm{F} 5$ and $\mathrm{F} 10$.

- Trough cross stratified sandstones (F5) are the most common deposits in this association. Sandstones are medium- to coarse-grained, with scattered granules to pebbles, and occur interbedded with F10 and F4. This facies occurs as 30 to $50 \mathrm{~cm}$ thick lenses or in cut-and-fill structures (Fig. 2h).

\section{Provenance analysis}

The braided river facies association was analyzed in three sites, one of them near the fault zone and the two others away from the basin border. Fluvial conglomerates are mostly composed of granite and mylonitic granite clasts, resulting in a scattered distribution of the plots in the diagram (Fig. 3). Quartz-mylonite clasts are rarer than in alluvial fan deposits, while rhyolite clasts are more common, surpassing the granite and mylonite granite contribution. As in the alluvial fan deposits, rhyolite clasts are more common with the increase in distance from the basin border fault.

\section{Petrography}

Samples from braided river deposits consist of poorly sorted, coarse-grained sandstones with sub-angular to angular grains. The packing is close; however, the pores 
show some evidence of an early cementation, later replaced by diagenetic cements.

\section{Interpretation}

All three facies in this association are interpreted as traction current deposits in bed-load dominated fluvial streams. Cross-stratified pebbly sandstones of F4 and F5 record subaqueous dune migration in fluvial streams, whereas conglomerates (F10) are interpreted as longitudinal bars deposits. The presence of bar deposits, the dominance of bedload strata accumulated within shallow channels, and the lack of flood-plains facies, altogether suggest that this facies association represents a braided river system.

\section{Vertical Stacking and Lateral Facies Variations}

Seven columnar sections were studied (Fig. 5), five of them located in a set of outcrops near the basin border fault, whereas two others are located approximately $2 \mathrm{~km}$ basinward. In the five sections close to the basin border there are clear facies changes, with the dominant alluvial fan facies changing into eolian deposits (Fig. 5), the last ones prevailing in the two distal sections. Thus, the alluvial fan deposits pinch out basinward, with the consequent thickening of the eolian deposits (Fig. 4). A disconformity at the boundary with the braided river deposits of Serra do Apertado Formation is seen in all sections.

Vertical facies changes are defined in some sections by the dominance of alluvial fan facies at the base, interdune facies at the transition and eolian dunes facies to the top.

\section{ARCHITECTURAL ELEMENTS ANALYSIS}

The architectural elements analysis (Miall 1985, 1996) was applied to the identification and hierarchization of surfaces that represent changes or interruptions on the depositional processes and mark the boundary among bodies with definite geometry, such as fluvial channels or interdunes.

The application of architectural elements analysis to eolian deposits was based on the classification of surfaces proposed by Brookfield (1977) and Kocurek (1988). According to these authors, first order surfaces in eolian deposits are the ones that represent climbing of dunes or draas, which may be associated with interdune deposits, resulting in surfaces with dips opposed to the depositional surfaces. Second order surfaces bound cross stratified sets and dip to the same direction as the cross strata, indicating dune climbing in the front of a draa. Third order surfaces represent small dip or direction change of dunes depositional surfaces, being analogous to the reactivation surfaces of subaqueous dunes.

Super-surfaces (Kocurek 1988) may trunk first order surfaces, present significant lateral continuity and have a relatively flat geometry, reflecting major paleogeographic change. Super-surfaces were used in section correlation in order to constrain lateral facies variations within each succession, and to define the spatial relationship between the eolian and the alluvial fan facies associations (Figs. 4 and 5). In the studied area, two super-surfaces were defined: super-surface 1 (SS1) is slightly irregular, and coincide with the boundary between alluvial fan deposits of the Pedra das Torrinhas Formation and the eolian dune field deposits of the Pedra Pintada Formation, while super-surface 2 (SS2) shows a planar geometry and represents the contact between the eolian dune field deposits of the Pedra Pintada Formation and braided river deposits by Serra do Apertado Formation.

Two architectural elements were recognized in the eolian dune fields association:

Eolian dunes are the main architectural element of these deposits, being characterized by the stacking of trough cross stratification sets as a result of barchan or barchanoid dune migration (McKee 1966, 1979). Reactivation surfaces (third order surfaces sensu Brookfield 1977) are abundant in this element, truncating the top of the F6 facies depositional surfaces. Second order surfaces are locally found and indicate the presence of draas (Fig. 9).

Wet interdune deposits comprise mostly F7 to F9 facies and minor F1. This element is related to the first order surfaces, disposed in lenses up to a few meters thick between bodies of the eolian dunes element (Figs. 6 and 9).

The alluvial fan facies association encompasses continuous successions of two architectural elements:

- Sheet-flood lobes are composed mainly of F2, and subordinate F1, disposed in tens of meters wide and tabular bodies up to several meters thick (Fig. 8) 


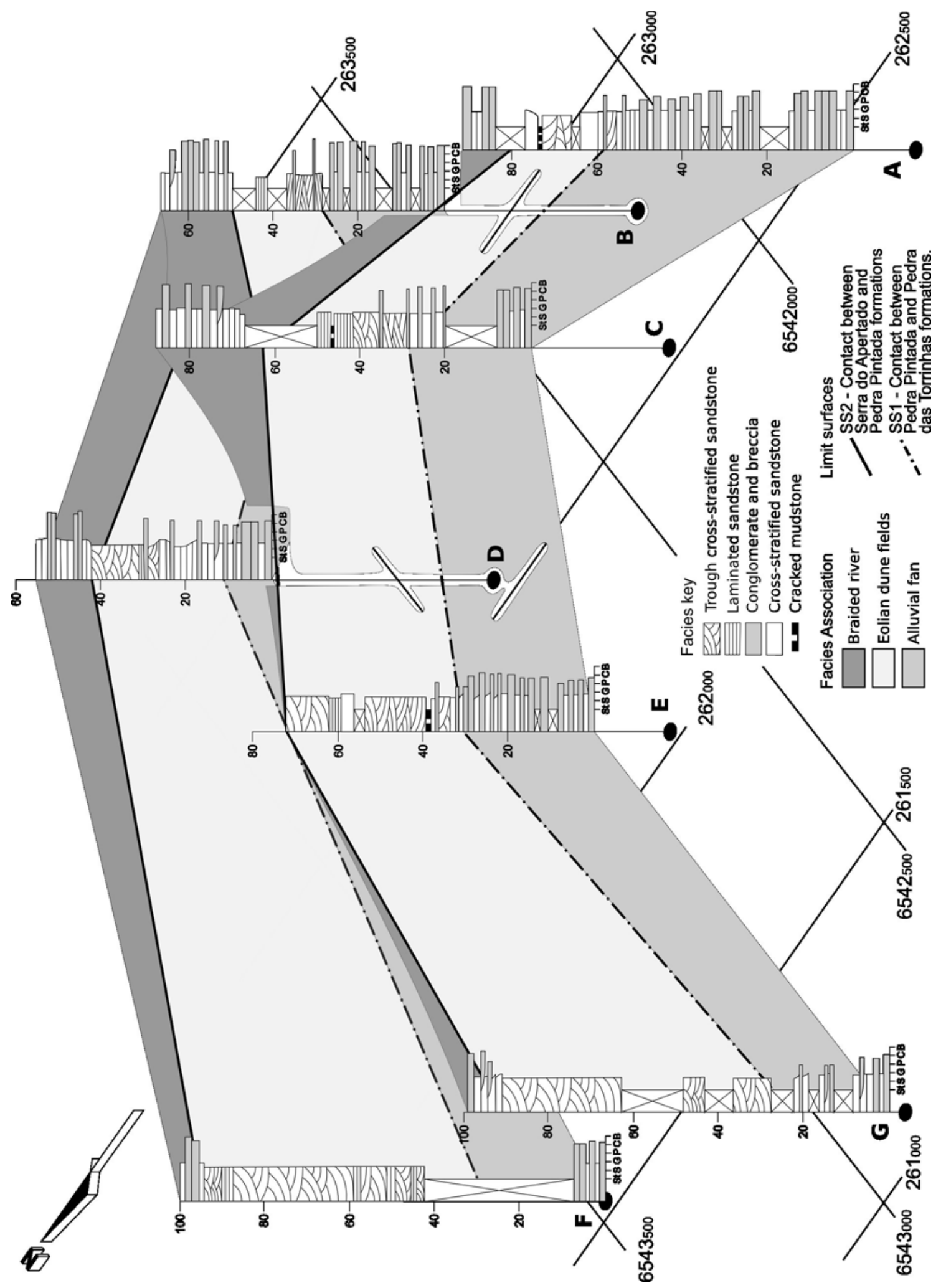

Fig. 4 - Fence diagram correlation for the columnar sections presented. Note the thickening of the eolian dune field facies association away (to the west) from the border fault (to the east). 

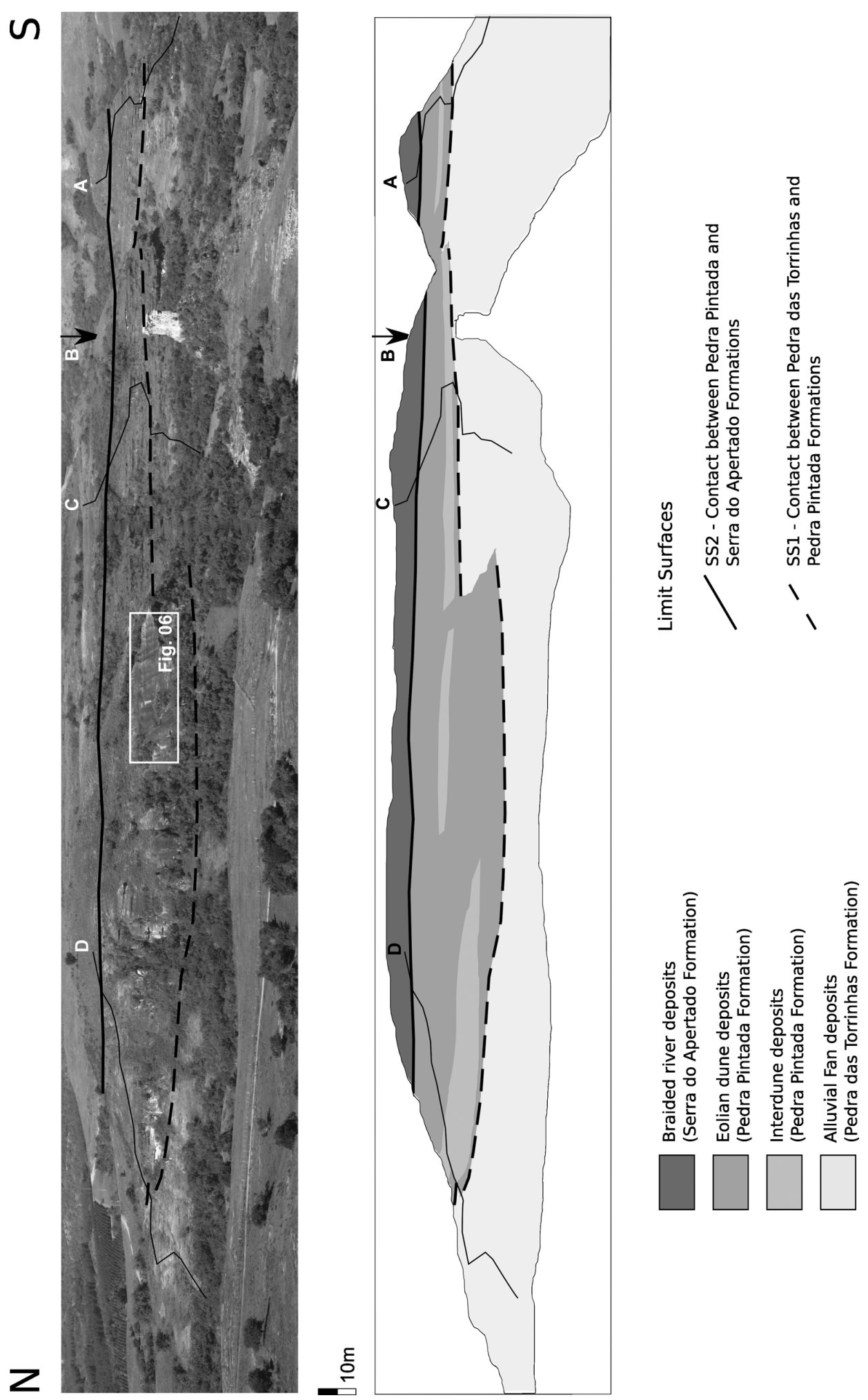

Fig. 5 - Location of the columnar sections and stratigraphical interpretation of the outcrops near the Encantadas Fault Zone. Notice the significant lateral change of the eolian and alluvial fan facies. Also observe the irregular nature of the SS1 (supersurface 1) in contrast with the planar aspect of SS2 (supersurface 2). The outcrops are in perspective, with section A farther from the viewer, and the section D closer to the viewer. 
$\mathrm{N}$
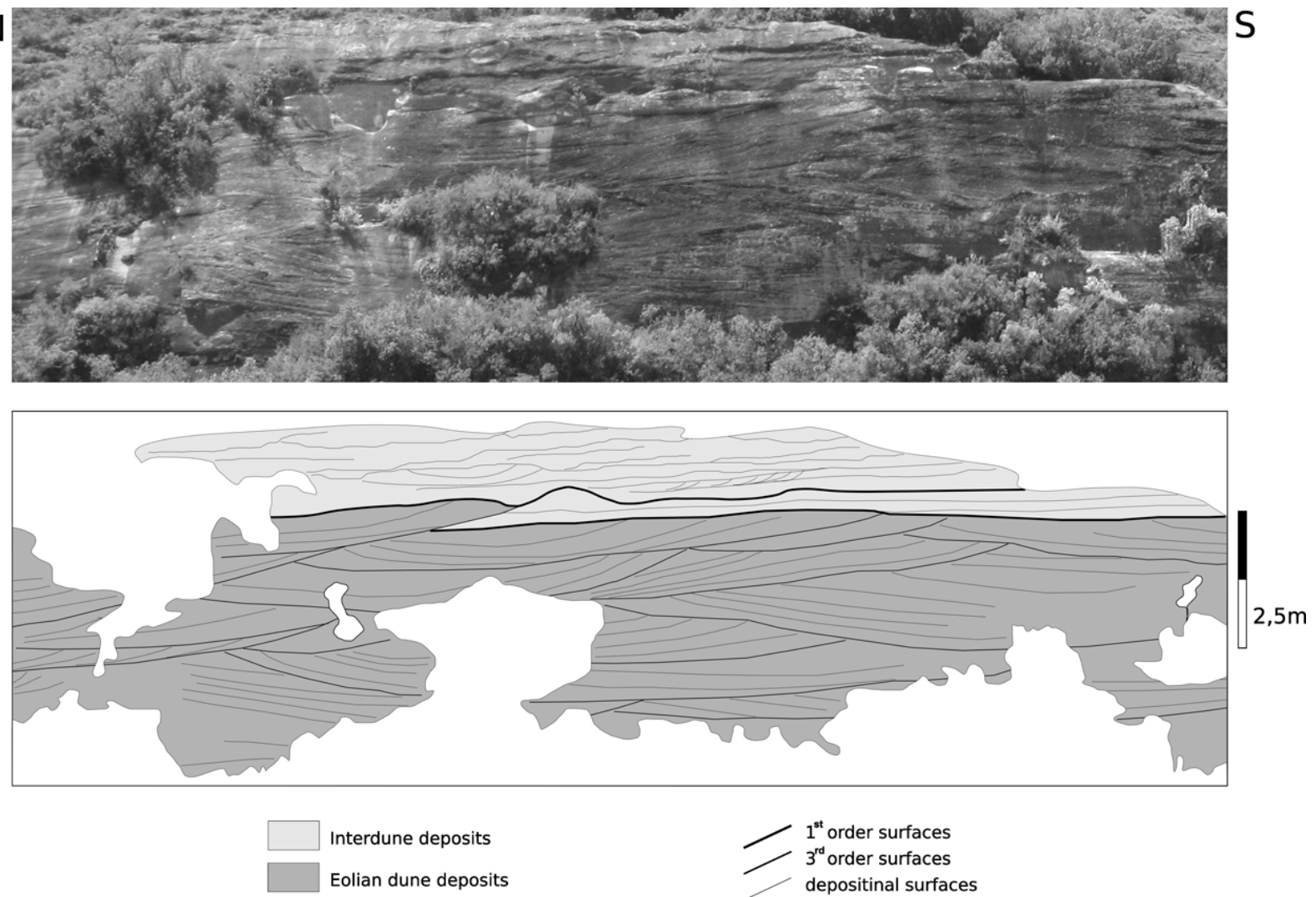

$1^{\text {st }}$ order surfaces

$3^{\text {rd }}$ order surfaces

depositinal surfaces

Fig. 6 - Detail of Figure 5 photomosaic showing the relationship between eolian dune and interdune deposits with the main bounding surfaces represented.

resulting from multiple sheet-flood events. Locally tabular beds of $\mathrm{F} 1$ facies (Fig. 8) prevails in thick successions possibly due to events with minor input or minor preservation of the sandy portion from the antidune collapse process interpreted to this facies (Blair 1999).

- Isolated Fluvial Channels are centimeter- to meter-thick, preserved as cut-and-fill structures within successions dominated by the sheet-flood lobes element (Fig. 8). These channels are filled with lower flow regime facies, dominantly F5, organized both as individual or amalgamated lenses. This architectural element is interpreted as the reworking of sheet flood unconfined flows deposits by minor channels scoured on top of sheet floods lobes after the peak discharge (waning flow strata), in a similar way as described by Blair (1987).

The Braided River facies association was not studied in terms of architectural elements analyses due to the limited extent of its outcrops.

\section{PALEOCURRENTS}

Paleocurrent data was collected mainly in cross-stratified facies from the three facies associations in order to interpret alluvial source areas and to reconstruct sediment dispersal patterns of both alluvial and eolian systems.

In the alluvial fan facies association, paleoflow measurements were obtained essentially in F4 and F5 facies, with some few data from F3. The mean direction of transport (Fig. 9) of the alluvial fan facies association was to WNW, nearly perpendicular to the Encantadas Fault Zone, which is considered to have been active during the sedimentation of the unit (Almeida 2005).

In the eolian facies associations, paleocurrents were obtained from trough cross-stratified sandstones of F6 facies. The mean direction of transport, obtained with considerable volume of data and with adequate data dispersal, was roughly NE (Fig. 9).

In the braided river facies associations, measurements were obtained in sandstones of F4 and F5 facies. 

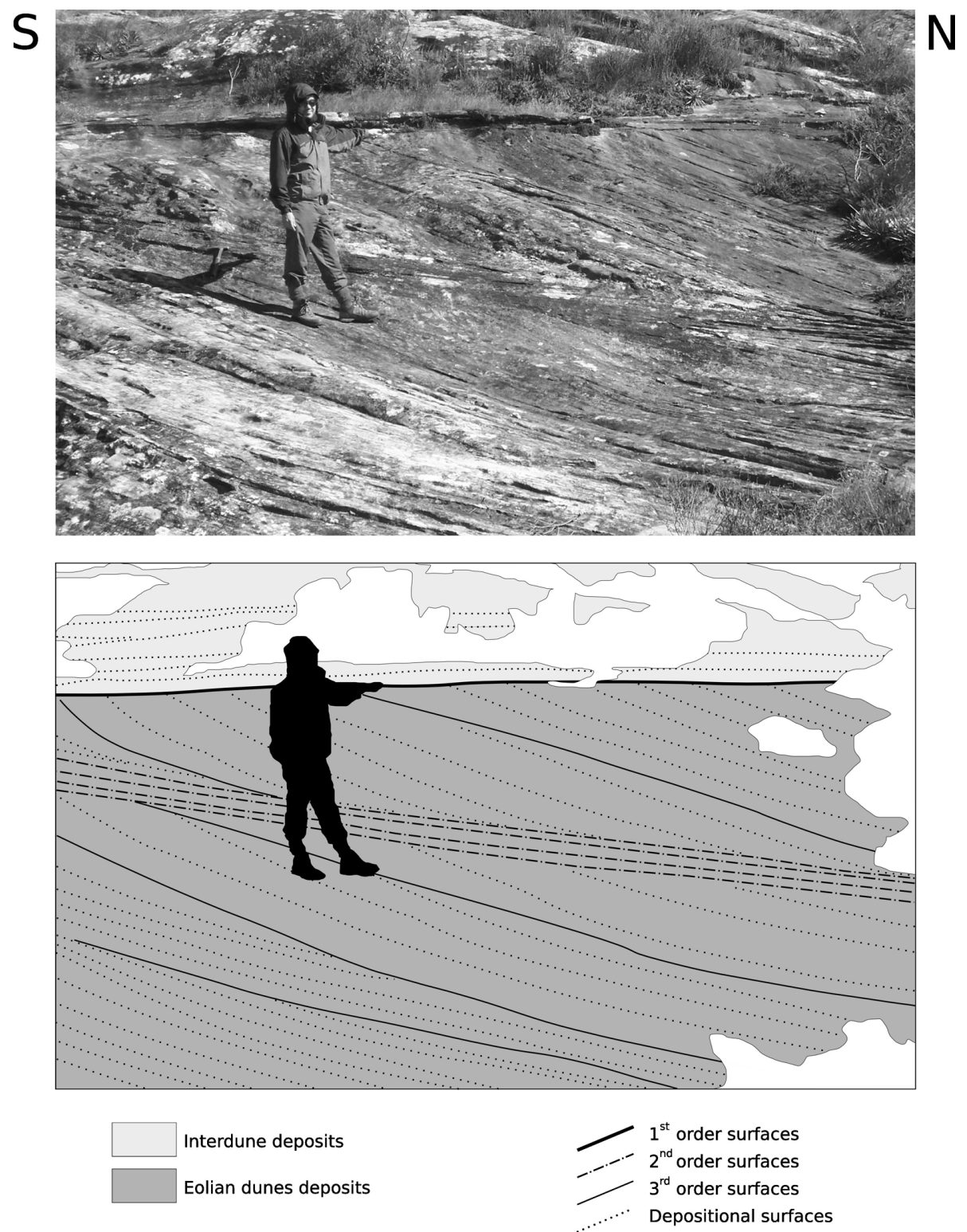

Fig. 7 - Photomosaic of the eolian dune field facies association showing the relationship between dune and interdune deposits and the main bounding surfaces. Note the $2^{\text {nd }}$ order surface that allows relating the dune deposit to a draa.

Like the alluvial fan facies association, the mean transport direction obtained for these deposits also points to NW, nearly perpendicular to the basin border, although presenting much narrower data (Fig. 9).

\section{POROSITY ANALYSIS}

A digital image analyser was used to perform the porosity analysis on thin sections impregnated with blue resin. The percentage of pores per area was obtained by mea- suring the area with blue pigment in digital images. Intergranular space, whether filled by cement or not, was visually estimated in order to evaluate possible controls of the type of deposit on the primary porosity (Table I).

Mean porosity in eolian dune deposits is $8.40 \%$, with a standard deviation of 4.51 , as an effect of the nearly continuous variation of the mean porosity, which ranges from $0.33 \%$ to $14.26 \%$ (Fig. 10a). Mean intergranular space is $12.54 \%$, with a lower standard deviation, of 2.33. Taking into account that the effects of 

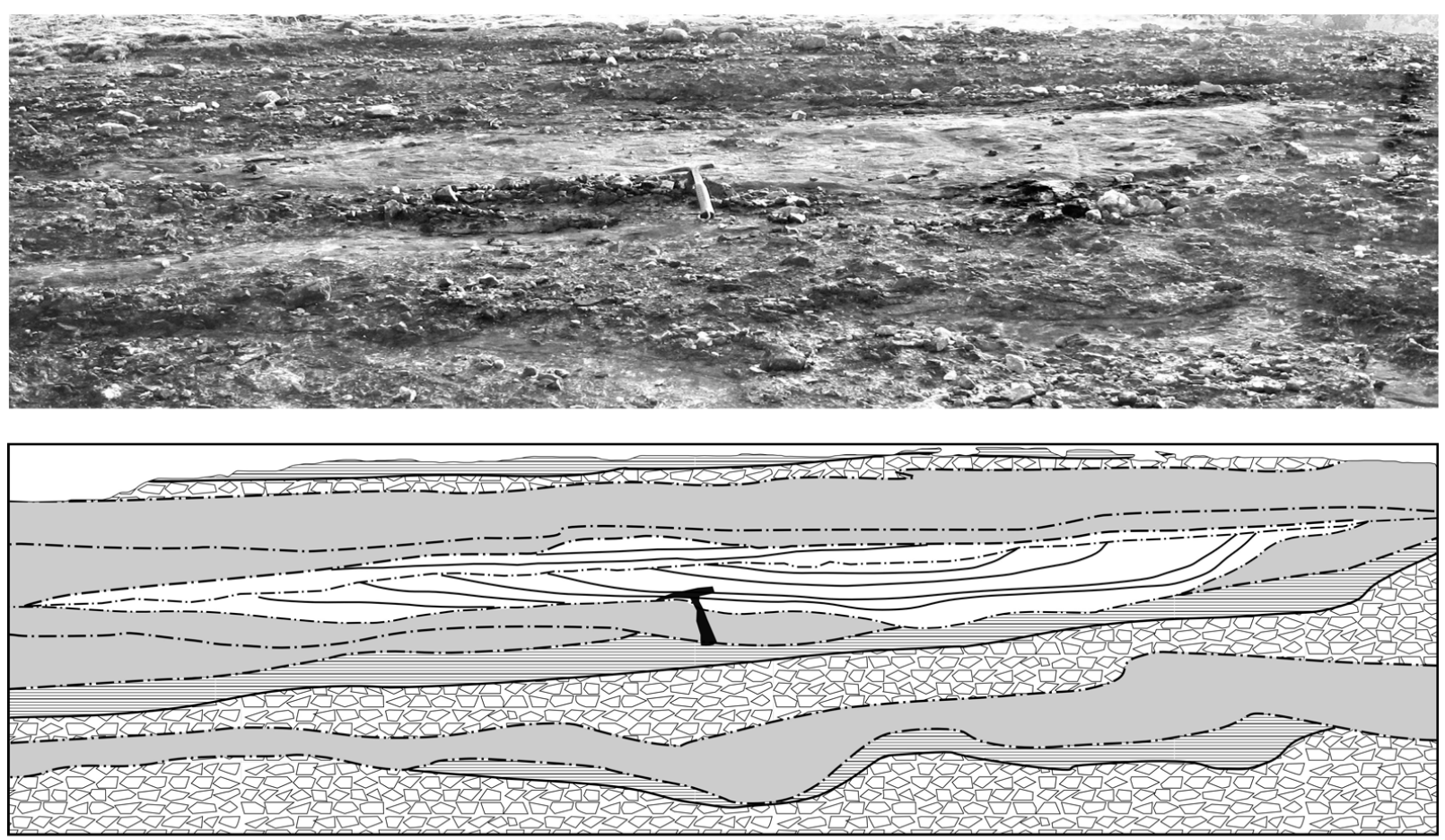

Architectural Elements

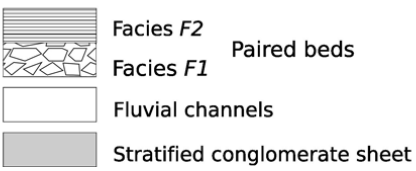

Limit Surfaces

Depositional surfaces

-.-.- Erosive surfaces

Fig. 8 - Photomosaic of the alluvial fan facies association showing relationship between the sheet-flood lobes and the isolated fluvial channels.

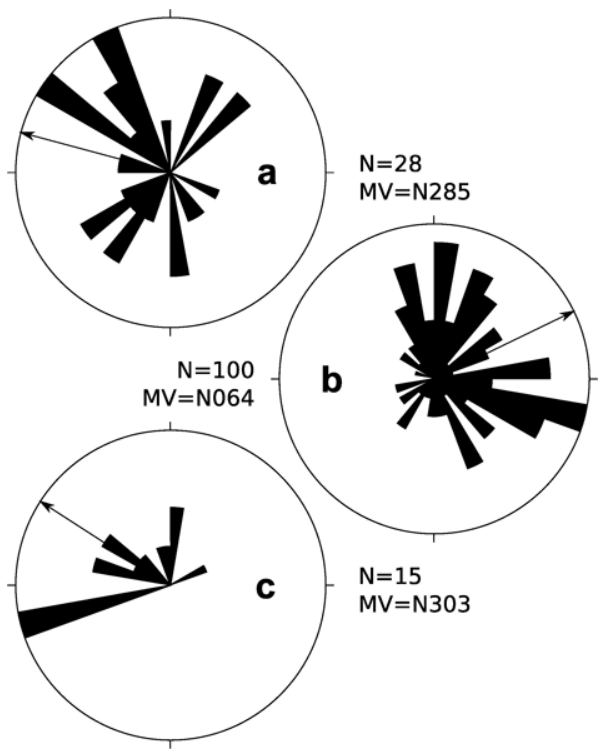

Fig. 9 - Rose diagrams for each facies association: a) alluvial fan; b) eolian dune field; c) braided rivers. Arrows represent the mean vector (MV), and $\mathrm{N}$ paleocurrent readings. 
TABLE I

Results of the porosity analysis.

\begin{tabular}{l|c|c|c|c}
\hline \multicolumn{1}{c|}{ Sedimentary deposits } & Eolian dunes & Interdunes & Alluvial fans & Braided rivers \\
\hline Mean porosity & 8.4 & 3.36 & 4.3 & 3.12 \\
\hline Standard deviation & 4.51 & 4.02 & 4.84 & 3.07 \\
\hline Minimum porosity & 0.33 & 0 & 0 & 0 \\
\hline Median porosity & 7.93 & 3.01 & 2.16 & 3.22 \\
\hline Maximum porosity & 14.26 & 11.22 & 13.14 & 6.13 \\
\hline Mean intergranular space & 12.54 & 8.44 & 7.5 & 10.67 \\
\hline Standard deviation & 2.33 & 4.8 & 3.63 & 2.31 \\
\hline Minimum intergranular space & 10 & 2 & 2 & 8 \\
\hline Median intergranular space & 12 & 10 & 8 & 12 \\
\hline Maximum intergranular space & 16 & 15 & 15 & 12 \\
\hline
\end{tabular}

cementation and secondary porosity are neglected in the visual evaluation of intergranular space, these higher values indicate that the original porosity (prior to compaction) was very high, possibly due to the good sorting of these deposits.

Interdune deposits present mean porosity of $3.36 \%$ and standard deviation of $4.02 \%$. This high standard deviation is the result of a wide porosity range, which spans from zero up to $11.22 \%$. The intergranular space is highly variable, with a mean value of $8.44 \%$ and a standard deviation of $4.88 \%$, which is higher than the deviation verified in the porosity (Fig. 10b). It is suggested that some samples had an early cementation, while other samples had less intergranular space as a result of poor sorting.

Samples from alluvial fan deposits present a mean porosity of $4.30 \%$, with a standard deviation of $4.84 \%$ (Fig. 12d), which is also the result of an almost continuous change in the porosity (zero to $13.14 \%$ ), with a median of $2.46 \%$, due to the large number of samples with null porosity. The mean intergranular space is $7.5 \%$, with a standard deviation of 3.63 , reflecting the heterogeneity among the alluvial fan samples.

Samples from fluvial deposits (Fig. 10c) exhibit the lowest mean porosity (3.12\%) and a standard deviation of 3.07, which is difficult to interpret due to the small amount of analyzed samples. Mean porosity ranges from zero to $6.12 \%$. When these values are compared to the mean intergranular space $(10.67 \%)$, which has a relatively small standard deviation, the importance of the cementation becomes evident on the preservation of the intergranular space, possibly due to early cements (prior to compaction) latter replaced by mesodiagenetic ones. Porosity higher than the intergranular space is related to samples with a substantial amount of secondary (intragranular) pores.

In a broad view, it can be concluded that there is a correlation between sedimentary facies and porosity values, with the highest, lowest and intermediate figures related to eolian dunes, interdune and braided river deposits, and alluvial fan deposits, respectively. If compared with the visual estimation of the intergranular space, porosity of eolian dune sandstones is still higher than in the others, suggesting that the main controlling factor on the porosity was the primary grain sorting.

It is worth to mention that the secondary porosity caused by superficial dissolution (cement and grains weathering) can have affected the presumed original porosity figures, since the samples were collected at outcrops.

\section{DISCUSSION AND CONCLUSIONS}

The characterization of facies association led to the recognition of a basinward transition from a basin border alluvial fan system to an eolian dune field system, which ultimately covers the alluvial fan deposits. At the transition among these facies associations, two types of alluvial-eolian interaction were set apart. A direct influence of alluvial fans in the dune field is shown by pebbly sheet-flood deposits within interdune strata. On the other hand, the eolian reworking of alluvial fan facies was identified in thin sections with abnormal sorting.

This interaction is connected to a non-vegetated topographic high at the basin border related to an active 

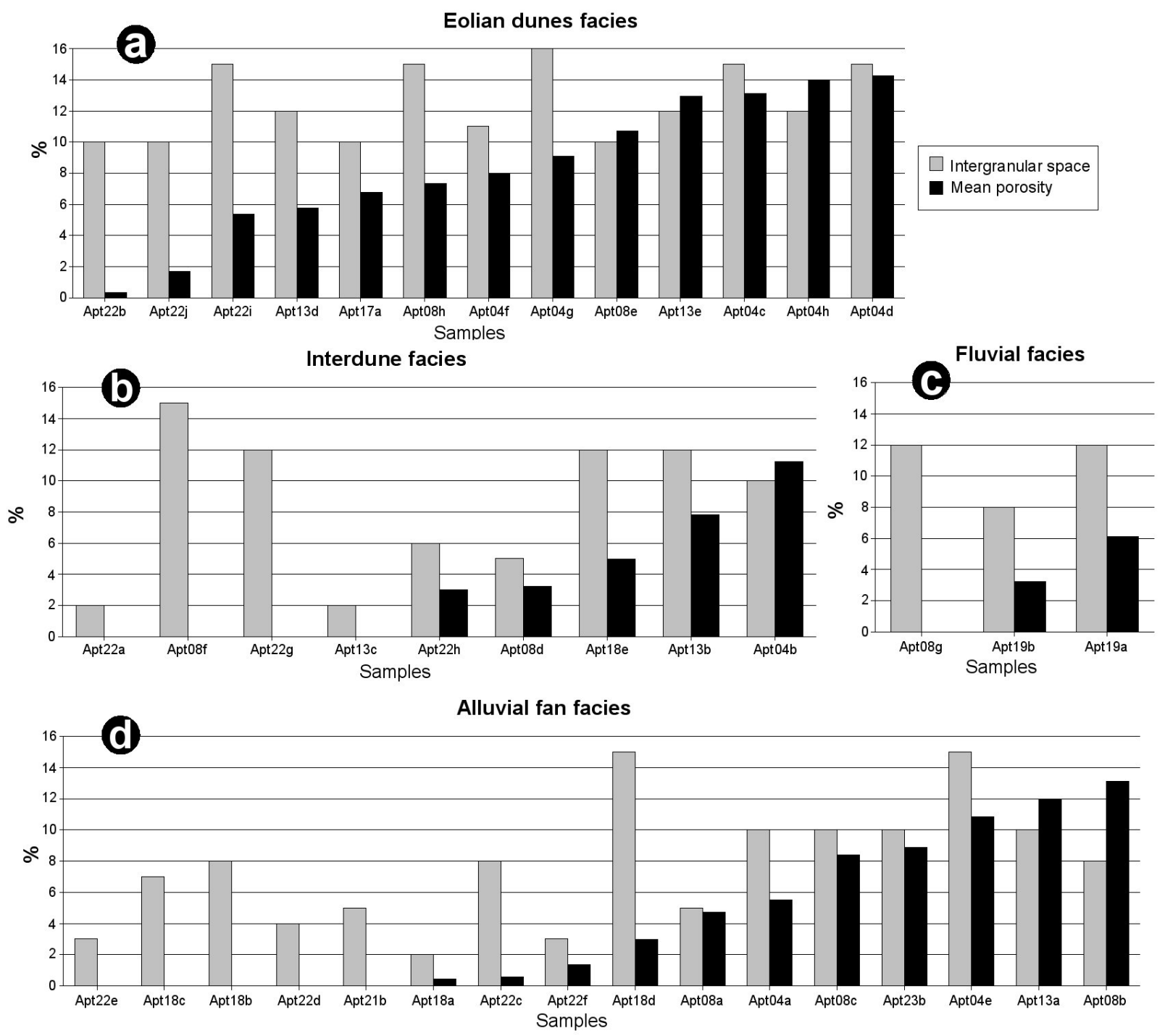

Fig. 10 - Bar diagrams contrasting porosity and intergranular space in the distinct facies associations. a) Eolian dune deposits; b) Interdune deposits; c) Braided river deposits; d) Alluvial fan deposits.

normal faulting during the deposition of the Guaritas Group, as well as moisture availability, once the alluvial fan main source rocks were located in the topographic high. Similar systems are expected in rift basins of arid settings formed after the evolution of land plants. Furthermore, these depositional systems would be typical on any rift border subaerial succession of Early Paleozoic or older age, despite climate conditions.

Provenance data suggest distinct sources for the alluvial fan and braided river facies associations. The alluvial fan main sources are the nearby basement exposed at the basin border, where mylonites and mylonitic granites crop out. Differently, braided river deposits show a distinct assemblage of clast lithotypes, suggesting a wider drainage caption area. Despite that, paleocurrent data reveal that both associations had a transport direction nearly perpendicular to the border fault.

Petrographic analysis highlights the facies control on porosity, including a significant porosity increase due to eolian reworking of former alluvial deposits. Grain sorting and grain size are the main controlling agents on porosity, followed by cementation and compaction.

The integration of porosity and architecture reveals that the alluvial-eolian interactions have produced complex porosity heterogeneities at the facies association scale. The interlayering of interdune and alluvial fan 
deposits in eolian dune systems could cause a reduction in the bulk permeability, although not yielding true permeability barriers. Consequently, analogous deposits could behave as good water and hydrocarbons reservoirs, even though the presence of interbedded interdune and alluvial fan deposits (both difficult to identify in geophysical surveys) could affect the total porosity of the sedimentary deposit.

\section{ACKNOWLEDGMENTS}

The authors thank the support from the Fundação de Amparo à Pesquisa do Estado de São Paulo (FAPESP) (grants 06/50655-0 and 06/59724-4).

\section{RESUMO}

O presente trabalho consiste no estudo de afloramentos da Formação Pedra das Torrinhas do Grupo Guaritas (Cambriano, Bacia Camaquã), próximo à Zona de Falha das Encantadas. As sucessões estudadas incluem depósitos de leques aluviais que passam lateralmente para depósitos eólicos. Foram realizadas análises de fácies e de elementos arquiteturais, seguidos de petrografia sedimentar e análise microscópica de porosidade, com o objetivo de caracterizar a porosidade da unidade e sua distribuição espacial. O principal objetivo foi contribuir para uma melhor compreensão da distribuição espacial de porosidade em sistemas deposicionais caracterizados pela interação aluvial-eólica, com atenção especial à sistemas deposicionais pré-vegetação. A porosidade é controlada principalmente pelos processos deposicionais, com os valores maiores associados a depósitos de dunas eólicas (média de 8,4\%) e os menores a facies de interdunas (média de 3,4\%) e de leques aluviais (média de 4,3\%). A análise dos elementos arquiteturais mostra a relação espacial destes depósitos, provocada por interações entre sistemas deposicionais aluviais e eólicos. A integração de dados revela que a interação de processos aluviais e eólicos resultou em uma complexa heterogeneidades na escala de associação de facies. O retrabalhamento eólico de fácies aluviais provocou aumento de porosidade enquanto que a ocorrência de enchentes-em-lençol em áreas de interduna e o aporte de sedimentos aluviais em interdunas inundadas formaram corpos sedimentares com porosidade reduzida.

Palavras-chave: interação aluvial-eólica, Formação Pedra das Torrinhas, Cambriano, modelos análogos de reservatório, fácies de margem de rift.

\section{REFERENCES}

ALMEIDA RP. 2005. Tectônica e sedimentação do Ediacarano ao Ordoviciano: exemplos do Supergrupo Camaquã (RS) e do Grupo Caacupé (Paraguai Oriental). Tese de Doutorado, Instituto de Geociências, Universidade de São Paulo, São Paulo, SP, Brasil, 203 p.

Almeida RP, Janikian L, Fragoso-Cesar ARS AND MARCONATO A. 2009. Evolution of a rift basin dominated by subaerial deposits: the Guaritas Rift, Early Cambrian, Southern Brazil. Sediment Geol 217: 30-51.

BECKER R AND FERNANDES LAD. 1982. Caracterização faciológica de uma sequência vulcano-sedimentar eoPaleozóica na Folha Passo do Tigre RS. Acta Geol Leo 6: 287-322.

BLAIR TC. 1987. Sedimentary processes, vertical stratification sequences and geomorphology of the Roaring River alluvial fan, Rocky Mountain National Park, Colorado. J Sediment Res 57: 1-18.

BLAIR TC. 1999. Cause of dominance by sheetflood vs. Debris flow processes on two adjoining alluvial fans, Death Valley, California. Sedimentology 46: 1015-1028.

Blair TC AND MCPherson JG. 1994. Alluvial fans and their natural distinction from rivers based on morphology, hydraulic, sedimentary processes and facies assemblages. J Sediment Res 64: 450-489.

BROOKFIELD ME. 1977. The origin of bounding surfaces in ancient aeolian sandstones. Sedimentology 24: 303-332.

BrookfIELd ME. 1992. Eolian systems. In: WALKeR RG AND JAMES NP (Eds), Facies models: response to sea level change, Geological Association of Canada. Geotext 1: $143-156$.

Bullard JE AND Livingstone I. 2002. Interactions between Aeolian and fluvial systems in dryland environments. Area 34: 8-16.

Clemmensen LB And Abrahamsen K. 1983. Aeolian stratification and facies association in desert sediments, Arran Basin (Permian), Scotland. Sedimentology 30: 311-339.

Collinson J. 1996. Alluvial Sediments. In: ReAding HG (Ed), Sedimentary environments, processes, facies and stratigraphy, Oxford: Blakcwell Science, $2^{\text {nd }}$ ed., p. 3782.

El-Baz F, Maingue M And Robinson C. 2000. Fluvioaeolian dynamics in the north-eastern Sahara: the relationship between fluvial/aeolian systems and ground water concentration. J Arid Environ 44: 173-183. 
Fischer C, Gaupp R, Dimke M And Sill O. 2007. A 3D high resolution model of bounding surfaces in Aeolianfluvial deposits: an outcrop analogue study from the Permian Rotliegend, Northern Germany. J Petrol Geol 30: 257-274.

Fragoso-Cesar ARS. 1991. Tectônica de Placas no Ciclo Brasiliano: as orogenias dos Cinturões Dom Feliciano e Ribeira no Rio Grande do Sul. Tese de Doutorado, Instituto de Geociências, Universidade de São Paulo, São Paulo, SP, Brasil, 366 p.

Fryberger SG And Schenk CJ. 1988. Pin stripe lamination: a distinctive feature of modern and ancient eolian sediments. Sediment Geol 55: 1-15.

Gardner TW, Webb J, Davis AG, Cassel EJ, Pezzia C, Merritts DJ AND SMith B. 2006. Late Pleistocene landscape response to climate change: eolian and alluvial fan deposition, Cape Liptrap, southeastern Australia. Quaternary Sci Rev 25: 1552-1569.

HADLARi T, RAINBIRD RH AND DONALDSON JA. 2006. Alluvial, eolian and lacustrine Sedimentology of a Paleoproterozoic half-graben, Baker Lake Basin, Nunavut, Canada. Sediment Geol 190: 47-70.

HARMS JC. 1979. Primary Sedimentary Structures. Ann Rev Earth Planet Sci 7: 227-248.

HERRIES RD. 1993. Contrasting styles of fluvial-aeolian interaction at a downwind erg-margin: Jurassic KayentaNavajo transition, northeastern Arizona, USA. In: NORTH CP AND PRosser DJ (Eds), Characterization of fluvial and aeolian reservoirs. Geol Soc London, Spec Publ 73: 199-218.

HUNTER R. 1977. Basic types of stratification in small eolian dunes. Sedimentology 24: 361-387.

KoCUREK G. 1988. First order and super bounding surfaces in eolian sequences - bounding surfaces revisited. Sediment Geol 56: 193-206.

Kocurek G. 1996. Desert aeolian systems. In: READING HG (Ed), Sedimentary environments, processes, facies and stratigraphy, Oxford: Blackwell Science, $2^{\text {nd }}$ ed., p. 125-153.

LANGFORD RP. 1989. Modern and ancient fluvial-eolian interactions: Part1, Modern systems. Sedimentology 36: 1023-1035.

LANGFORD RP AND CHAN MA. 1989. Modern and ancient fluvial-eolian interactions: Part 2, Ancient systems. Sedimentology 36: 1038-1051.

LAVINA EL, FACCINI UF, PAIM PSG AND FragosoCESAR ARS. 1985. Ambientes de sedimentação na Bacia do Camaquã, Eo-paleozóico do Rio Grande do Sul. Acta Geol Leo 21: 185-227.

Maroulis JC, Nanson GC, Price DM And Pietsch T. 2007. Aeolian-fluvial interaction and climate change: source bordering dune development over the past $\sim 100 \mathrm{ka}$ on Cooper Creek, central Australia. Quaternary Sci Rev 26: 386-404.

MCKEE ED. 1966. Structures of dunes at the White Sands National Monument, New Mexico. Sedimentology 7: 369.

MCKEE ED. 1979. Introduction to a study of global sandseas. US Geol Surv Prof Paper 1052: 1-19.

Miall AD. 1985. Architectural-element analysis: a new method of facies analysis applied to fluvial deposits. Earth-Sci Rev 22: 261-308.

Miall AD. 1996. The Geology of Fluvial Deposits: Sedimentary Facies, Basin Analysis and Petroleum Geology, Berlin: Springer, $852 \mathrm{p}$.

Miall AD. 2000. Principles of sedimentary basin analysis, New York: Springer-Verlag, $3^{\text {rd }}$ ed., 616 p.

PAIM PSG. 1994. Depositional Systems and Paleogeographical Evolution of the Camaquã and Santa Bárbara Basins, Brazil. Ph.D. thesis, Oxford, 277 p.

PAIM PSG. 1995. Alluvial palaeogeography of the Guaritas Depositional Sequence of Southern Brazil. International Association of Sedimentologists Special Publication, Oxford 22: 3-16.

PAIM PSG AND SCHERER CMS. 2003. Arquitetura estratigráfica de sucessões flúvio-eólicas: o exemplo do Alogrupo Guaritas na região da Pedra Pintada, Rio Grande do Sul, Brasil. In: PAim PSG, Faccini UF AND NetTo RG (Eds), Geometria, arquitetura e heterogeneidades de corpos sedimentares - Estudo de casos. Unisinos, p. 3858.

PAIM PSG AND SCHERER CMS. 2007. High-resolution stratigraphy and depositional model of wind- and waterlaid deposits in the Ordovician Guaritas rift (Southernmost Brazil). Sediment Geol 202: 776-795.

Paim PSG, Chemale JR. F And Lopes RC. 2002. A Bacia do Camaquã. In: Holtz M AND DeRos LF (Eds), Geologia do Rio Grande do Sul, CIGO/UFRGS, p. 231274.

REAding HG. 1986. Facies. In: ReAding HG (Ed), Sedimentary Environments and Facies, $2^{\text {nd }}$ ed., p. 4-19.

RibeIRo M. 1970. Geologia da Folha de Bom Jardim, Rio Grande do Sul, Brasil. Boletim da Divisão de Geologia e Mineralogia - DNPM 247: 1-142. 
Ribeiro M And Lichtenberg E. 1978. Síntese da Geologia do Rio Grande do Sul. In: CONGRESSo BRASILEIRO De Geologia 30, Recife, PE, SBG, Anais... 6: 24512463.

ROBERTSON JF. 1966. Revision of Stratigraphy and nomenclature of rock units in Caçapava-Lavras Region. Notas e Estudos, IG-UFRGS 1: 41-54.

Stanistreet IG and Stollhofen H. 2002. Hoanib River flood deposits of Namib Desert interdunes as analogues for thin permeability barrier mudstone layers in aeolianite reservoirs. Sedimentology 49: 719-736.

Stromback A, Howell JA And Veiga GD. 2005. The transgression of an erg - sedimentation and reworking/ soft-sediment deformation of aeolian facies: Cretaceous Troncoso Member, Neuquén Basin, Argentina. In: VEIGa GD, Spalletti LA, Howell JA AND Schwarz E (Eds), The Neuquén Basin, Argentina: A Case Study in Sequence Stratigraphy and Basin Dynamics. Geol Soc London, Spec Publ 252: 163-183.
Tоотн S. 2000. Process, form and change in dryland rivers: a review of recent research. Earth Sci Rev 51: 67-107.

Veiga GD and Spalletti LA. 2007. The Upper Jurassic (Kimmeridgian) fluvial-aeolian systems of the southern Neuquen Basin, Argentina. Gondwana Res 11: 286-302.

WALKER RG. 1975. Conglomerate: Sedimentary structures and facies models. In: DEPOSITIONAL ENVIRONMENTS AS INTERPRETED FROM PRIMARY SEDIMENTARY Structures and Stratification Sequences. Soc Econ Paleont Miner, Short Course Notes 2: 133-161.

WALKer RG. 1992. Facies, facies models and modern stratigraphic concepts. In: WALKER RG AND JAMES NP (Eds), Facies Models and Response to Sea-level Change, Geological Association of Canada. Geotext 1: 1-14.

Went DJ. 2005. Pre-vegetation alluvial fan facies and processes: an example from the Cambro-Ordovician Rozel Conglomerate Formation, Jersey, Channel Islands. Sedimentology 52: 693-713. 